\title{
Private governance and accounting for sustainability networks
}

DOI:

$10.1177 / 0263774 X 15604841$

\section{Document Version}

Proof

Link to publication record in Manchester Research Explorer

\section{Citation for published version (APA):}

Thistlethwaite, J., \& Paterson, M. (2015). Private governance and accounting for sustainability networks.

Environment and Planning C: Government and Policy, [0263774X15604841].

https://doi.org/10.1177/0263774X15604841

\section{Published in:}

Environment and Planning C: Government and Policy

\section{Citing this paper}

Please note that where the full-text provided on Manchester Research Explorer is the Author Accepted Manuscript or Proof version this may differ from the final Published version. If citing, it is advised that you check and use the publisher's definitive version.

\section{General rights}

Copyright and moral rights for the publications made accessible in the Research Explorer are retained by the authors and/or other copyright owners and it is a condition of accessing publications that users recognise and abide by the legal requirements associated with these rights.

\section{Takedown policy}

If you believe that this document breaches copyright please refer to the University of Manchester's Takedown Procedures [http://man.ac.uk/04Y6Bo] or contact uml.scholarlycommunications@manchester.ac.uk providing relevant details, so we can investigate your claim.

\section{OPEN ACCESS}




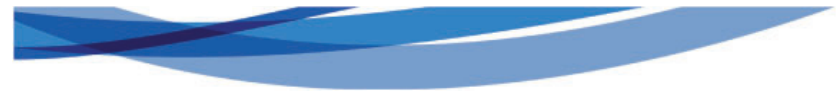

(9SAGE

\section{Page Proof Instructions and Queries}

Journal Title: $\quad$ Environment and Planning C: Government and Policy (EPC)

Article Number: 604841

Greetings, and thank you for publishing with SAGE. We have prepared this page proof for your review. Please respond to each of the below queries by digitally marking this PDF using Adobe Reader.

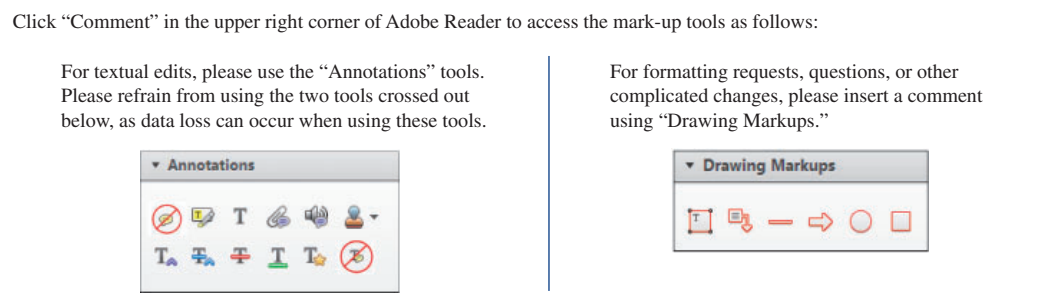

Detailed annotation guidelines can be viewed at: http://www.sagepub.com/repository/binaries/ pdfs/AnnotationGuidelines.pdf

Adobe Reader can be downloaded (free) at: http://www.adobe.com/products/reader.html.

\begin{tabular}{|c|c|}
\hline No. & Query \\
\hline & $\begin{array}{l}\text { Please confirm that all author information, including names, affiliations, } \\
\text { sequence, and contact details, is correct. }\end{array}$ \\
\hline & $\begin{array}{l}\text { Please review the entire document for typographical errors, mathematical } \\
\text { errors, and any other necessary corrections; check headings, tables, and } \\
\text { figures. }\end{array}$ \\
\hline & $\begin{array}{l}\text { Please confirm that the Funding and Conflict of Interest statements are } \\
\text { accurate. }\end{array}$ \\
\hline & $\begin{array}{l}\text { Please ensure that you have obtained and enclosed all necessary permissions } \\
\text { for the reproduction of artistic works, (e.g. illustrations, photographs, charts, } \\
\text { maps, other visual material, etc.) not owned by yourself. Please refer to your } \\
\text { publishing agreement for further information. }\end{array}$ \\
\hline & $\begin{array}{l}\text { Please note that this proof represents your final opportunity to review your } \\
\text { article prior to publication, so please do send all of your changes now. }\end{array}$ \\
\hline AQ: 1 & $\begin{array}{l}\text { Please provide complete details for "Avant et al. (2010)" or allow us to delete } \\
\text { the citation. }\end{array}$ \\
\hline AQ: 2 & $\begin{array}{l}\text { Please provide complete details for "Bulkeley and Castán Broto, 2013; } \\
\text { Bulkeley et al., 2015; Hoffmann, 2010" or allow us to delete the citations. }\end{array}$ \\
\hline AQ: 3 & $\begin{array}{l}\text { Please provide complete details for "Carroll (2010)" or allow us to delete the } \\
\text { citation. }\end{array}$ \\
\hline AQ: 4 & Please mention the footnote number here. \\
\hline AQ: 5 & $\begin{array}{l}\text { Please provide complete details for "Paterson, } 2001 \text { and (2010)" or allow us } \\
\text { to delete the citations. }\end{array}$ \\
\hline
\end{tabular}




\begin{tabular}{|c|c|}
\hline AQ: 6 & $\begin{array}{l}\text { Please provide complete details for "van Appeldoorn and de Graaf, 2014," } \\
\text { "Faulconbridge and Muzio, 2012" and "Vucetic, 2011" or allow us to delete } \\
\text { the citations. }\end{array}$ \\
\hline AQ: 7 & Please provide expansion for ENGO. \\
\hline AQ: 8 & Please clarify whether "Seabrooke, 2014" refers to (2014a) or (2014b) here. \\
\hline AQ: 9 & Please provide expansions for "WBCSD" and "WRI" \\
\hline AQ: 10 & $\begin{array}{l}\text { Please provide accessed date for "A4S (2014)," "American Institute of } \\
\text { Certified Public Accountants (2009)," and "AccountAbility (2013)", }\end{array}$ \\
\hline AQ: 11 & Please provide volume and page range for "Adams J (2007)." \\
\hline AQ: 12 & $\begin{array}{l}\text { "Andonova et al. (2009)" is not cited in text. Please cite in text or allow us to } \\
\text { delete the citation. }\end{array}$ \\
\hline AQ: 13 & Please provide publisher location for "Botzem S (2008)." \\
\hline AQ: 14 & $\begin{array}{l}\text { Please provide accessed date for "Carbon Tracker (2012), (2014)," “CDSB } \\
(2012),(2013),(2014), " \text { "Ernst \& Young (2013)," "European Coalition for } \\
\text { Corporate Justice (2013)," "Gore Al and Blood D (2013)," and "CDP } \\
\text { (2013)" }\end{array}$ \\
\hline AQ: 15 & Please provide complete details for "CDSB (2010a), (2010b)"] \\
\hline AQ: 16 & $\begin{array}{l}\text { "CDSB (2010a)" is not cited in text. Please cite in text or allow us to delete } \\
\text { the reference.] }\end{array}$ \\
\hline AQ: 17 & $\begin{array}{l}\text { Please provide publisher location for "Clapp J and Utting P (2009)" and } \\
\text { "Cutler et al. (1999)."] }\end{array}$ \\
\hline AQ: 18 & $\begin{array}{l}\text { Please provide accessed date for "IASB (2008)," “IIRC (2013a), (2013b), } \\
(2013 \mathrm{c}),(2013 \mathrm{~d}),(2013 \mathrm{e}) \text {, }\end{array}$ \\
\hline AQ: 19 & $\begin{array}{l}\text { "IIRC (2013e)" is not cited in text. Please cite in text or allow us to delete the } \\
\text { reference.] }\end{array}$ \\
\hline AQ: 20 & $\begin{array}{l}\text { Please provide accessed date for "King et al. (2012)," "KPMG (2009)," } \\
\text { "Leggett J (2012)," "Living Economies Forum (2013)," "Martinez-Diaz L } \\
(2005),\end{array}$ \\
\hline AQ: 21 & Please provide page range for "Miller P (1994)." \\
\hline AQ: 22 & $\begin{array}{l}\text { Please provide volume and page range for "Overdevest C and Zeitlin J } \\
(2012) . "\end{array}$ \\
\hline AQ: 23 & Please provide publisher location for "Rogers G (2005)." \\
\hline AQ: 24 & Please provide journal name for "Sadler D and Lloyd S (2009)." \\
\hline AQ: 25 & Please provide accessed date for "SASB (2013a), (2013b), (2013c), (2013d)." \\
\hline AQ: 26 & Please provide page range for "Seabrooke L (2014a)." \\
\hline AQ: 27 & Please provide volume and page range for "Seabrooke L (2014b)." \\
\hline AQ: 28 & Please provide accessed date for "The Economist (2014)." \\
\hline AQ: 29 & Please provide page range for "Tsingou E (2010)." \\
\hline AQ: 30 & Please provide biographies for the authors. \\
\hline
\end{tabular}




\section{Private governance and accounting for sustainability networks}

\author{
Jason Thistlethwaite
}

University of Waterloo, Canada

\section{Matthew Paterson}

University of Ottawa, Canada
Environment and Planning C: Government and Policy 0 (0) I-24

(C) The Author(s) 2015

Reprints and permissions: sagepub.co.uk/journalsPermissions.nav DOI: $10.1177 / 0263774 X 1560484$ I epc.sagepub.com

@SAGE

\begin{abstract}
Accounting rules and practices have become an important component of the governance of sustainability, notably in the field of corporate environmental, social, and governance reporting. This paper analyses the emergence and character of private governance initiatives regarding sustainability accounting. It does so using social network analysis in order to be able to conceptualize the patterns of connection across these different initiatives, and thus contribute to three specific ways that these initiatives are understood theoretically-as privatized neoliberal governance, via notions of professional epistemic authority, and through the concept of experimentation and experimental governance.
\end{abstract}

\title{
Keywords
}

Private governance, sustainability accounting, social network analysis, professions, experimentation

\section{Introduction}

Accounting has become a dense site of activity for private environmental governance. This is especially the case for sustainability accounting initiatives (SAI), a unique field of private governance designed to align environmental, social, and governance (ESG) reporting with financial accounting. These initiatives are important because they deal with a key potentially transformative part of the global economy - the question of how investors and corporate managers attribute value to sustainability aspects of their investments/corporate decisions. Their effect and importance are thus arguably more profound than other areas of private environmental governance such as product certification or standard setting. In a world where the structural power of the financial industry ${ }^{1}$ is important to shape investment and productive activities, the technical knowledge of accountants attains a particular place in the

\section{Corresponding author:}

Jason Thistlethwaite, University of Waterloo, 200 University Ave Environment 3, Ring Rd Waterloo, Ontario, Canada N2L 3GI.

Email: jasonthistlethwaite@me.com 
overall governance of sustainability. In the climate change context, this has gained significant recent attention with ongoing debates about a potential "carbon bubble," "stranded assets," and of the motivations behind divestment from fossil fuels (e.g., Carbon Tracker, 2012; Gore and Blood, 2013; Leggett, 2012; The Economist, 2014). While this concern has not yet prevented fossil fuel companies from continuing to invest in fossil fuel exploration and extraction (Carbon Tracker, 2014), SAI has nevertheless the potential to increase the materiality of these risks for investors by transforming their understanding of the links between their practices and outcomes for sustainability. Transparency through improvements in accounting practices could therefore lead to a transformation of capitalism, as capital is reallocated toward more sustainable and low-carbon economic activity.

What however is the political character and dynamics of this field of governing activity? There is already a fair amount of research and literature on individual initiatives (such as the Carbon Disclosure Project [CDP] or the Global Reporting Initiative [GRI]) that seek to govern sustainability via corporate reporting and disclosure (Brown et al., 2009; Kolk et al., 2008). There is also a good deal known in general about the politics of accounting governance (Botzem, 2008; Perry and Nolke, 2006; Porter, 2005; Power, 1997). But we know much less about the organizational character of the field where financial accounting and sustainability reporting practices are combined. We term these initiatives seeking to combine these two distinct fields of practice as SAI and we analyze nine such initiatives in this article. These are instances of private governance, or collaborations designed to generate a public good that is either missing or undersupplied in the international system (Clapp, 1998; Falkner, 2003; Green, 2014; Pattberg, 2007).

But who, following the useful question of Avant et al. (2010), are the individuals and organizations that participate in the development of these rules? How are the different initiatives connected to each other via these individuals? And what can we learn from analyzing these patterns of connection about the politics of SAI as a whole? We address these questions in this article principally through the use of social network analysis (SNA). This is a method that is designed to capture some important aspects of how the various initiatives are connected to each other and thus a whole "field" of SAI governance could be said to exist. Approaching this question via SNA allows us to see patterns of connection across a whole field of governance rather than focusing only on individual governing initiatives, and thus extends Avant et al.'s question of "who are the governors" in important ways. SNA cannot answer all the questions we might want to ask of this field, but it can make important contributions in our view. We supplement the SNA with documentary and historical analysis of the initiatives involved.

We use these methods to explore three specific arguments in the general literature on private governance in this article. We develop these accounts in more detail below, but briefly, these are the following. First is a perspective that situates private governance in the macro-politics of neoliberalism, seeing it as an appropriation or privatization of governance by corporate (especially financial) actors, and at the same time as a contested space as nongovernmental organizations (NGOs) seek to govern corporate activity in the absence of state regulation (e.g., Clapp, 1998; Newell, 2001; Nolke and Perry, 2007). The second is a perspective that places more emphasis on the agency and autonomy of professional actors (such as accountants) who seek to govern via their particular epistemic commitments and authority (e.g., Seabrooke, 2014a). And the third is a perspective that seeks to explain governance in novel arenas such as that of sustainability accounting in terms of a logic of experimentation (e.g., Bulkeley and Castán Broto, 2013; 
Our aim in this article is neither to claim to decide definitively in favor of one or other of these arguments nor to generate a general theoretical synthesis. While it is possible to see these three as competing interpretations of SAI, we emphasize rather their potential complementarities. Specifically, we see the limits of existing literature focused on the SAI as neoliberalization of environmental governance, which we see as the dominant approach in the literature, less as residing in basic problems of this perspective, but rather in its tendency to focus on the "macro" dynamics at the expense of the "micro" nuances of how these governance initiatives emerge and what in practice they do. The focus on professionalization sheds more light on the particular agents that mediate between large-scale forces of neoliberalization and specific initiatives, while the notion of experimentation enables us to understand better the particular dynamics of learning and iteration that occurs when agents are faced with radically new governance challenges such as that of governing sustainability disclosure via accounting systems. Both of these also complicate the conceptualization of the public-private distinction prevalent in notions of neoliberalization as well as in debates about transnational governance (Bulkeley et al., 2012; Pattberg and Stripple, 2008), as we draw on conceptions of public and private as a "collection of social practices" rather than a "bounded realm or space" (Best and Gheciu, 2014). These however do not call into question the larger scale dynamic that is nevertheless one of corporate and financial domination of these governance initiatives, as well as the effectively privatized nature of such governance, key features of neoliberal forms of environmental governance.

Using SNA to examine SAI as a collection of individual connections and practices with a field of related initiatives, the limits of a distinction between "private" and "public" and the interests of "capital" and "civil society" become increasingly clear. The patterns of connection between the actors and organizations involved in this process defy such simple categorization. Similarly, the different types of authority (Avant et al., 2010) on which governance might be based (institutional, expertise, etc) blur into each other in complicated ways when we explore the network connections across a field of governance. Moreover, when the field of SAI is viewed as a site of experimentation and professionalization, these concepts add important nuance to the framing of private governance as neoliberalization, by focusing on the strategy behind SAI, emerging alliances designed to distance participants from their existing professional allegiances, and conflicts that reveal significant uncertainty. Research on professionalization and the public-private divide confirms that establishing the credibility necessary to generate compliance for new rules or standards requires a process whereby the actors involved form new interests that are separate from their principal organizations, which are bounded by their public or private mandates (Bernstein, 2014). In addition, experimentation involves active efforts to expand deliberation that has the potential to "re-politicize" often abstract and obscure accounting rules traditionally designed to reduce markets' uncertainty into technical decisions that favor the interests of profit-maximizing shareholders. Firms, civil society actors, and public authorities have an opportunity through experimentation to not only question the technical requirements of ESG reporting but also pressure the accounting industry ${ }^{2}$ to help advance societal rather than strictly financial interests. This uncertainty and its resolution are dependent on continual deliberation and intersubjective learning rather than public or private trade-offs and is thus "open-ended rather than closely circumscribed" (Paterson, 2014, 168).

\section{Methods}

In order to assess these three theoretical approaches to transnational private environmental governance, we explore empirically the patterns of agency, interaction, and learning involved 
Table I. Sustainability accounting initiatives.

\begin{tabular}{|c|c|c|}
\hline Initiative & Dates & Description \\
\hline Global Reporting Initiative (GRI) & 1997 & $\begin{array}{l}\text { Initiated by Ceres to provide a global } \\
\text { database on corporate ESG information } \\
\text { for investors }\end{array}$ \\
\hline $\begin{array}{l}\text { World Business Council for Sustainable } \\
\text { Development (WBCSD) }\end{array}$ & 1998 & $\begin{array}{l}\text { GHG Protocol (jointly organized with } \\
\text { WRI), system for measuring project or } \\
\text { corporate-level carbon emissions }\end{array}$ \\
\hline $\begin{array}{l}\text { United Nations Environment Program } \\
\text { Finance Initiative (UNEP-FI) }\end{array}$ & $1998-2000$ & $\begin{array}{l}\mathrm{CO}_{2} \text { benchmarking initiative, measuring } \\
\text { corporate carbon emissions }\end{array}$ \\
\hline Carbon Disclosure Project (CDP) & 2000 & $\begin{array}{l}\text { Investor-led governance initiative focused } \\
\text { on corporate reporting of aggregate } \\
\text { emissions }\end{array}$ \\
\hline Accounting for Sustainability (A4S) & 2004 & $\begin{array}{l}\text { Oversees a network of accountants } \\
\text { working on new rules that help } \\
\text { integrate sustainability into accounting } \\
\text { practices }\end{array}$ \\
\hline $\begin{array}{l}\text { Carbon Disclosure Standards Board } \\
\text { (CDSB) }\end{array}$ & 2007 & $\begin{array}{l}\text { A partnership between several ESG } \\
\text { reporting organizations to integrate } \\
\text { climate change risks into mainstream } \\
\text { financial reporting standards }\end{array}$ \\
\hline $\begin{array}{l}\text { International Corporate Governance } \\
\text { Network (ICGN) }\end{array}$ & 2008 & $\begin{array}{l}\text { An investor-led governance initiative } \\
\text { designed to improve corporate } \\
\text { governance }\end{array}$ \\
\hline $\begin{array}{l}\text { International Integrated Reporting Council } \\
\text { (IIRC) }\end{array}$ & 2010 & $\begin{array}{l}\text { Initiated by the GRI and A4S to develop a } \\
\text { set of internationally recognized } \\
\text { reporting standards that integrate } \\
\text { sustainability and financial information }\end{array}$ \\
\hline $\begin{array}{l}\text { Sustainability Accounting Standards Board } \\
\text { (SASB) }\end{array}$ & 2011 & $\begin{array}{l}\text { A US based organization seeking to } \\
\text { integrate ESG information into financial } \\
\text { reports }\end{array}$ \\
\hline
\end{tabular}

Note: ESG: environmental, social, and governance; GHG: greenhouse gas; A4S: Accounting for Sustainability.

in nine ESG reporting initiatives that emerged in the late 1980s and early 1990s. Table 1 outlines these initiatives. A significant general development over the period of time is that alongside the development of initiatives for general sustainability accounting rules, specific initiatives focused on carbon emissions have emerged, reflecting a general, if not universal, "carbonification" (Stephan, 2012) of environmental politics. The article aims to explore questions such as: who is involved in the development of these initiatives? How do different types of actors interact? What can we infer from the development over time of these networks of actors and initiatives?

Empirically, we proceed by combining three specific methods to explain SAI strategy and make inferences about whether and in what ways these connections show patterns of co-optation and contestation, professionalization, and/or learning and experimentation. First, we provide a narrative historical analysis of the emergence of ESG initiatives, in the section that follows.

Second, we undertake a SNA of the participants in the initiatives (Scott, 2012). SNA is a method that has come to be increasingly used to help understand the relational aspects of governance initiatives, including, in the area of environmental governance, studies of policy 
diffusion of emissions trading systems (Paterson et al., 2014), studies of the relations between carbon certification schemes (Green, 2013), and of the transnational organization of NGO alliances (Hadden, 2014). We use it here to identify the people and organizations that connect the initiatives we analyze, and organize those connections chronologically (since we know when each initiative was established). An important premise here is that it is useful to explore the whole field of ESG governance, and therefore the connections between the initiatives if we want to understand patterns of neoliberal contestation, processes of professionalization or of learning and experimentation. Most of the existing literature on sustainability accounting, and private governance more broadly, is on individual initiatives (Andrew and Cortese, 2013; Brown et al., 2009; Kolk et al., 2008; Lovell and MacKenzie, 2011). As we show below, many of the initiatives are closely connected in terms of participation by different organizations and individuals and their development over time as a field of private governance. SNA is central to demonstrate this.

We explore SAI as a social network in the following way. First, the network is primarily understood as a set of connections between the nine initiatives. The nodes that connect the initiatives are principally individual people but can also be the organizations they work for. The network is constituted by the current members of the board. ${ }^{3}$ Boards are used as the data source since they are the principal sites of strategic decision making within the organization. In this we follow Carroll's (2010) analysis of transnational corporate elites, where board connections between transnational firms are analyzed to explore the social structure of transnational corporate organization. In addition, in these organizations, the boards and the expert networks overlap significantly, given that many initiatives are started and governed by actors claiming epistemic authority in this field. The network is thus an affiliation network whereby connections between individuals are established simply by common participation in the same ESG initiative (as is the case in Carroll's analysis, 2010, and also in Paterson et al., 2014). In the network images we display below, nodes can thus be either individual people, organizations they work for, and (in the case of a two-mode network, where two types of node can be displayed) the initiatives themselves.

We collected additional demographic data on the individual participants and the organizations they work for. Specifically, we collected data concerning their training, both where they studied and in what they were trained. We coded their careers according to profession, on the basis of both professional training and their actual work roles, in addition to citizenship. This was designed to enable us to see patterns of connection between the different initiatives via not only individuals but also via employing organizations, universities training members of the network, and countries. The results were analyzed in Ucinet and visualized in Netdraw (Borgatti et al., 2002).

There are of course limits to the data, notably the ability to generate data across time. With the exception of the United Nations Environment Programme's Finance Initiative (UNEP FI) initiative, where we did have archive data available, the data on the other initiatives are for contemporary (2013-2014) participants in each initiative, which will inevitably miss some connections of people who used to be involved but no longer are (we give an example of one known absence in a footnote). Nevertheless, the SNA makes a useful contribution, capturing aspects of the relations between the initiatives and the character of the whole network missed by other methods.

Analytically, a key measure used is that of betweenness. This is a measure of the centrality of particular nodes in a network. For our networks, the betweenness score is a useful measure in making inferences about the centrality of particular individuals or organizations to control information flows across the network, and to act as 
entrepreneurs linking up different initiatives, since technically, it is a measure of the likelihood that any given journey across the network has to pass through that node.

Third, we combine this narrative history and SNA, with content analysis of discussions surrounding the disclosure frameworks established within the initiatives themselves in order to explore the internal conversations within the initiatives. Specifically, we explore the frameworks adopted by each initiative in addition to the comments made on draft accounting rules within the initiatives, made by various stakeholders for the initiatives, as evidence of the character of these internal conversations.

\section{The convergence of financial accounting and ESG reporting}

ESG reporting first emerged in the 1970 s as a strategy driven by stakeholders including NGOs, consumers, and ethical investors to strengthen corporate accountability for the social and environmental impacts of firm behavior (Brown et al., 2009; Gray, 2001; Gupta, 2008). In response to this pressure, corporations would release information on reports that could help these external stakeholders track the firm's progress (Clapp and Utting, 2009). As the popularity of reporting increased in the 1990s, NGOs, firms, and investors started to organize private governance initiatives designed to develop reporting standards that could help stakeholders compare firm ESG performance. The most notable initiatives included the Coalition for Environmentally Responsible Economies (Ceres), and the GRI (Brown et al., 2009; Pattberg, 2007).

Several other groups recognized a growing demand among investors for information that linked ESG information to financial risk, and started to develop their own expertise and standards. This effort was initially pioneered by the UNEP-FI, which was formed in $1994 .^{4}$

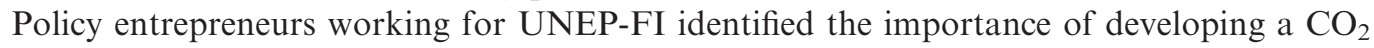
benchmark that could be used to measure how portfolios contributed to greenhouse gas (GHG) emissions and their contributions to financial risk (Paterson, 2001; Newell and Paterson, 2010: 72). This idea was adopted by the CDP, which was formed in 2002, and has now become the world's most popular standard for climate change risk reporting through the deployment of an annual survey to the world's largest publicly listed firms (CDP, 2013; Macleod and Park, 2011). The Greenhouse Gas Protocol (GHG Protocol) also emerged in 2001 and, similar to the CDP, now represents the most widely used standard for corporate measurement of GHG emissions (Green, 2010, 2013).

The emergence these reporting initiatives constituted a distinct field of private governance aimed at facilitating social change by promoting an "intense discourse about accountability, corporate social responsibility and the appropriate roles for the business, government, civil society and professional sectors in the sustainability transition" (Brown et al., 2009: 195; see also Pattberg, 2007). As these initiatives developed, however, they increasingly turned to the expertise of financial accountants to improve the capacity of ESG reports to leverage investors and their control over capital as a means of reducing social and environmental impacts. These developments produced the later initiatives in our data set, the Accounting for Sustainability (A4S), Climate Disclosure Standards Board (CDSB), International Integrated Reporting Committee (IIRC), and Sustainability Accounting Standards Board (SASB).

Financial accountants are trained to reduce information asymmetries between investors and their investments and improve market efficiency by measuring and communicating a publicly listed firm's financial information (Rogers, 2005; see also Thistlethwaite, 2011). To ensure measurement and communication of financial information is comparable between firms, financial accountants rely on reporting standards based on the financial reporting 
model (IASB, 2008). This model is designed to establish a threshold for information considered "decision-useful" for disclosure in financial statements using the concepts of "materiality" and "cost-benefit." Financial information is decision-useful if it is "material" to investors, meaning its omission from a financial statement would affect asset allocations. The cost-effective provision helps to limit the amount of information by stipulating that the benefits of disclosure must outweigh the costs for both investors and preparers (CDSB, 2010b: 18). By applying this expertise to ESG disclosure, financial accounting expertise can help align ESG information with financial statements that investors use to make asset allocation decisions within their portfolios.

For many practitioners and researchers, financial accounting represents a strict field of expertise confined to the accounting industry that is apolitical and designed to reflect a neutral interpretation of a firm's economic performance (Martinez-Diaz, 2005; Porter, 2005). However, other researchers argue that financial accounting must be viewed as a social practice that can be influenced to reflect certain interests, but also influences interests through its application to the measurement of financial information (Miller, 1994; Miller and O'Leary, 1987). Financial accounting, like ESG reporting, constitutes a distinct field of private governance shaped and applied by international and domestic accounting standard setters, accounting professional organizations, and practitioners in the financial accounting industry (Porter, 2005; Power, 1997). Indeed, accounting scholars have identified a trend whereby accounting firms are using their expertise to shape the auditing of corporate social and environmental reporting by assessing whether information that is disclosed aligns with the objectives of the report (O'Dwyer et al., 2011; Power, 1997). This paper is grounded in this latter conceptualization of accounting as a field and practice.

The A4S was launched in London in 2006 and constitutes the first initiative to seek the accounting sector's expertise in communicating ESG information in ways that align with interests of investors (A4S, 2014; Adams, 2007). The CDSB, also located in London, emerged in 2007 as a partnership between representatives from the accounting industry, and several existing ESG initiatives including the CDP, GHG Protocol, Climate Registry, Ceres, and the International Emissions Trading Associations. Whereas, A4S largely focused on the generation and dissemination of accounting expertise on ESG, the CDSB develops standards, such as its Climate Change Reporting Framework that aligns climate change risk information with mainstream financial reporting (CDSB, 2013). The IIRC was formed through a partnership between the GRI and A4S with the creation of a London-based secretariat in 2012. The IIRC has adopted a similar strategy to the CDSB, but targets a wider range of ESG information through the development of its International Integrated Reporting Framework, which combines both sustainability and financial information (IIRC, 2013b). Whereas the A4S, CDSB, and IIRC are all located in London, the SASB is the only U.S. based initiative seeking to integrate ESG into financial reports. The SASB was founded in 2011 and is located in Washington D.C. (SASB, 2013b).

While each of these SAIs are independent, they all embrace similar organizational characteristics that give professional accountants influence in the development of ESG standards, but rely on a board largely composed of the founding organizations for final approval. This is particularly the case for CDSB, IIRC, and SASB which initiate the standard setting process through the work of a technical group composed of accountants who are charged with development of an exposure draft (ED) (CDSB, 2014; IIRC, 2013b; SASB, 2013a). A public comment period generates feedback on the ED, which is then incorporated into the standards by the technical working groups and submitted to the board for final approval (CDSB, 2012; IIRC, 2013a; SASB, 2013a). As this analysis 
reveals, SAI demonstrates an evolution whereby the field of private governance where ESG reporting emerged is linked with the separate field of financial accounting.

\section{Accounting-led private governance: Contestation, professionalization, and experimentation}

The emergence of these initiatives provides an opportunity to explore a new field that combines two historically distinct areas of practices. We now explore these initiatives, and in particular their interrelations, via three sets of perspectives on such private governance, as outlined in the Introduction section.

\section{Neoliberal contestation}

Perhaps the most widespread understanding of private governance in general, and private governance more generally, is that it is characterized as a site of neoliberal contestation. This interpretation goes back to the emergence of notions of private governance in the 1990s (e.g., Clapp, 1998; Cutler et al., 1999; Sinclair, 1994), and remains a significant part of the literature. In this view, private governance arises because of the enhanced power of transnational corporate and financial actors produced by the liberalization of financial flows central to the neoliberal project from the early 1980s onward. In some instances (e.g., in Clapp's classic example of ISO14000) corporations based in the global North use this power to enhance their control over smaller firms in the South. In other cases, corporations enact private governance initiatives to forestall regulation by states on a given issue (Falkner, 2003; Pattberg, 2007). In others still, small groups of firms use such initiatives to create club goods.

Private governance also arises however because NGOs, including environmental NGOs, shift their strategy in neoliberal conditions away from a sole focus on state regulation of industry, toward a variety of strategies, some more combative, others more cooperative, to govern corporate practice (Newell, 2001). Private governance thus becomes a space of direct contestation between NGOs and corporations - in Gramscian terms a struggle of hegemony and counter-hegemony. In environmental governance, the competition between NGO-led and corporate-led standards in forest certification is perhaps the classic case (Cashore et al., 2004; Humphreys, 2006). The field of contestation worked therefore within overall neoliberal frameworks, but over the strength of standards to regulate industry and the question of who has legitimate authority to make such rules.

We can see the dynamics of neoliberalism clearly at play in the sustainability accounting field. First, much of the criticism of and opposition to these initiatives is couched precisely in terms of the way that it reinforces and reproduces corporate power and undermines the need for state regulation in this field (Andrew and Cortese, 2013; Malsch, 2013).

Critical accounting scholars argue that accountants will discount ESG information in favor of the "logic of the market" and over time "displace the core regulatory functions (over issues such as working conditions and environmental sustainability) from the state to the corporate sector" (Sadler and Lloyd, 2009: 613). Research on the politics of financial regulation confirms the accounting sector has interests in advancing Anglo-American interests in "control financialisation" by empowering investors through greater transparency over corporate behavior (Nolke and Perry, 2007), while the financial industry can leverage its technical expertise to influence regulation in ways that privilege market interests (Tsingou, 2010). Indeed, analysis of financial regulation has described how accountancy firms have invoked their professional expertise as accountants to generate 


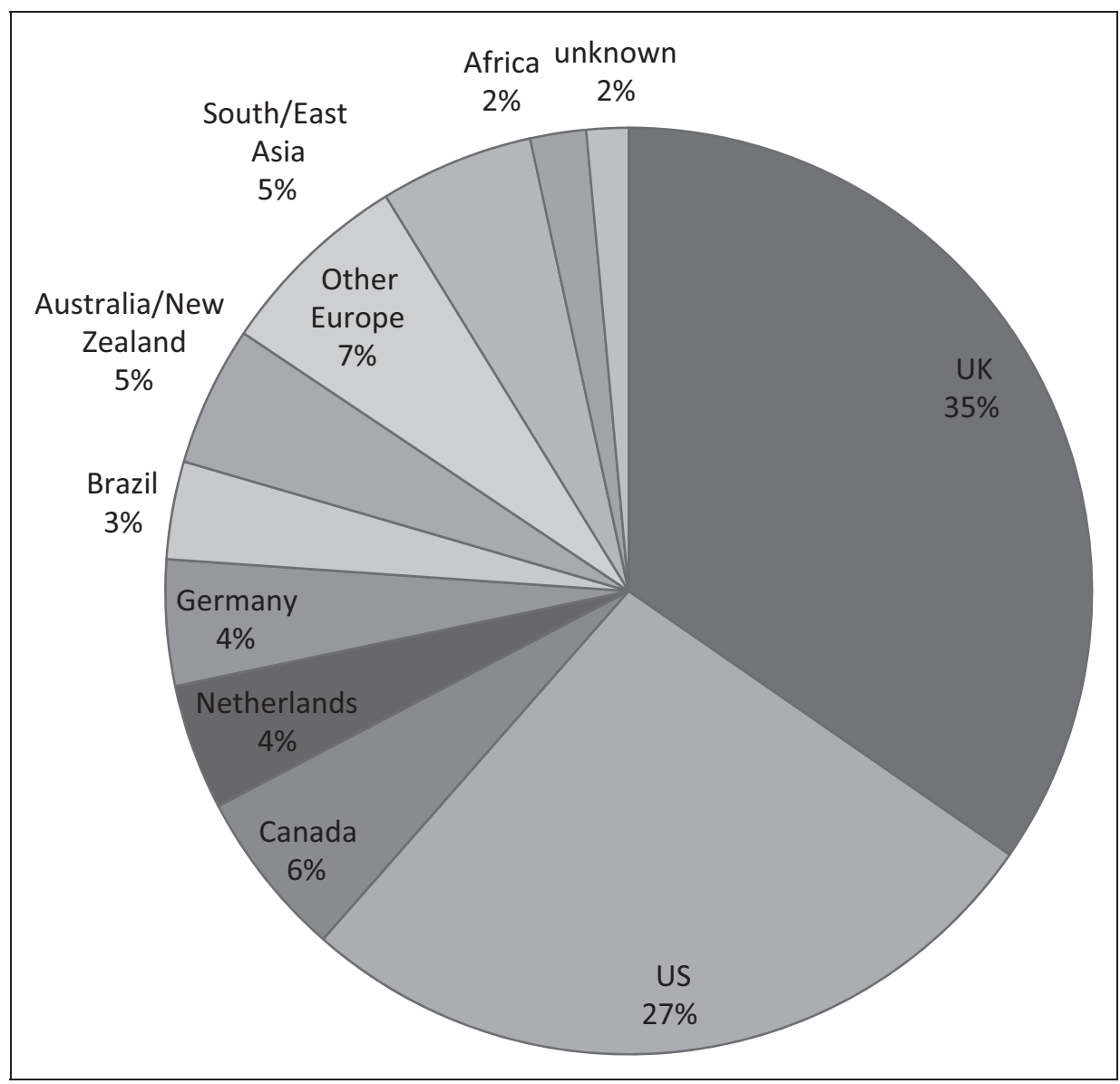

Figure I. Participation in sustainability accounting networks by country.

significant autonomy in decision making over international accounting standards (Buthe and Mattli, 2012; Porter, 2005). Research on corporate social responsibility reveals that firms can work to develop ESG standards as a means of defending their "institutional commons" from reputational and regulatory threats, thus further legitimating market logics (Barnett and King, 2008; King et al., 2012). More broadly, SAI initiatives could also reflect a structural shift toward the financialization of the economy as policy makers adopt neoliberal ideologies favoring market-oriented forms of governance (Clapp and Helleiner, 2012).

This neoliberal politics can be discerned reasonably clearly when we explore the field of SAI as a social network. One simple way to illustrate this is by looking at the country of origin of participants in SAI. Figure 1 shows the citizenship of those participating in these initiatives. It reveals considerable dominance by people from the US and the UK, the heartland of financialized neoliberalism. Individuals from these two countries account for $62 \%$ of the network as a whole. ${ }^{5}$ This is not necessarily a surprise, given the US/UK location of the "big 4" accountancy firms, their domination of transnational corporate organization in the "transnational capitalist class" (Carroll, 2010), and its elite networks (van Appeldoorn and de Graaf, 2014), as well as the general domination of world politics by actors from the 
"anglosphere" (Vucetic, 2011) and the structural advantage this confers on English speakers. Nevertheless this pattern is clear.

But while neoliberalism is associated with dominance by the US (and to a lesser extent the UK) it is more adequately understood as a form of financialized capitalism. Financialization has been used to describe the sectors' influence in promoting neoliberal policies that further entrench its influence, but also a transfer of power away from managers and employees to investors and shareholders (Nolke and Perry, 2007). The accounting industry empowers financial markets by standardizing and measuring economic activity in ways that favor short-term investment returns. The participation of the accounting sector in ESG disclosure debates is therefore a further symptom for the power of the financial industry in the global economy.

Figure 2 demonstrates this influence among ESG accounting initiatives. It shows a fourdegree network of employers as connected by accounting initiatives (that is to say, each line in the figure shows two organizations connected by a line are involved in at least four of the initiatives together). In similar figures for one, two, or three degree networks, a greater range of organizations figure as important (e.g., ENGOs like GRI, international organizations like UNEP), but the more densely connected we require organizations to be to each other, the more we end up with the big accounting and consultancy firms like Deloitte, PWC and 7 KPMG, or their professional associations, at the heart of the network.

This can be underscored also if we look at the organizations connecting the initiatives over time. Figure 4, later in the article, shows this. We should perhaps not over-interpret this, but there does appear to be a general shift over the time period from international organizations and NGOs toward accounting firms and their professional organizations as key connections within the network, which confirms the narrative history provided above.

In addition to nationality and the network of employers supporting SAI, the standards they are generating to report ESG information also reveals elements of neoliberal contestation. Indeed, the CDSB, IIRC, and SASB all require that ESG information is filtered using the financial reporting model (CDSB, 2012; IIRC, 2013b; SASB, 2013a). By requiring that ESG information is "decision-useful" to investors, and that the benefits of reporting exceed the costs, reporting organizations enjoy significant flexibility to ignore and discount the measurement of this information. NGOs participating in the consultations often argued that the financial reporting model disproportionately emphasizes investor perceptions, which could limit disclosure of hard to measure ESG impacts such as freshwater degradation (Living Economies Forum, 2013). For this reason, the financial reporting model must be expanded to adequately capture a wider range of ESG impacts, such as climate change, which may be more material to investors in the future (AccountAbility, 2013; European Coalition for Corporate Justice, 2013).

\section{Transnational epistemic arbitrage}

But the corporate domination story is only one way into exploring the social makeup of the network. The role of professional accountants we observe aligns with existing research that highlights the authority of the sector's expertise as a source of private governance (e.g., Buthe and Mattli, 2012), as well as with analysis of transnational governance that has revealed how professionals can compete over the expertise necessary to govern emerging issue areas, such as ESG reporting (Abbott, 2005; Seabrooke, 2014). According to Seabrooke, professions have considerable opportunity to engage in what he calls "epistemic arbitrage" where actors "play off different pools of knowledge for strategic advantage to position themselves and their preferred skill set and knowledge as the best 


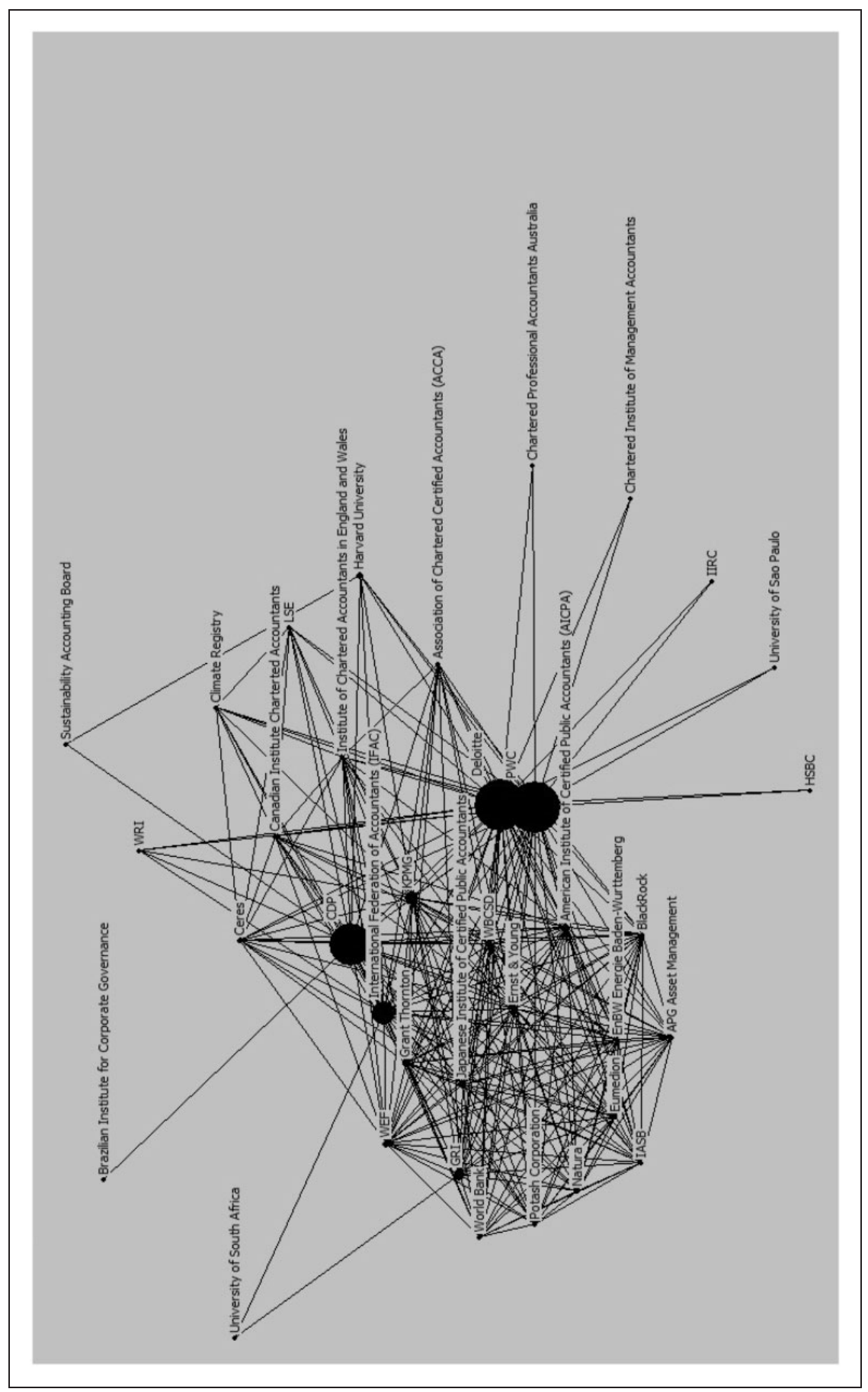

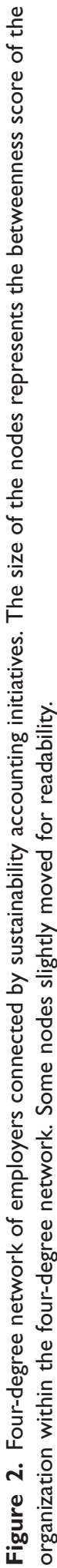


way to address problems" (Seabrooke, 2014a: 5; see also Faulconbridge and Muzio, 2012). Epistemic arbitrage is a process where legitimacy claims rely on knowledge rather than material wealth or broad ideologies such as neoliberalism.

In other words, professionals involved in transnational governance have significant autonomy from their "principals"- the agents that they formally work for. In this instance, it suggests that SAI initiatives cannot be reduced simply to agents of the financial industry, but rather that they are able to use their control over specialized accounting knowledge to engage in "epistemic arbitrage" between the competing arguments of investors on the one hand and civil society actors on the other. The former may in fact seek to avoid disclosure of sustainability-related information in many situations, since it would increase costs and reduce investment opportunities. By participating in SAI, stakeholders become "brokers" between investors and ESG proponents but also adopt identities as transnational actors that must balance the tension between corporate accountability and financial market efficiency, rather taking a position based on their professional obligations (Burt, 2010; Seabrooke, 2014b).

Figure 2 can also be read in relation to this sort of argument - the principal organizations involved in SAI are accountancy firms and accountancy professional bodies. We can explore this also via the individuals involved. Figure 3 shows the connections between SAI made by individual people. This is a two-degree network, meaning that individuals connected by a line participate together in at least two of the initiatives.

Figure 3 shows that the network of individuals connecting the nine SAI has a relatively small number of key brokers - individuals playing a role in some way in connecting up the network as a whole. It is worth elaborating a little on these individuals. Table 2 shows the 17 individuals with the highest betweenness scores (a measure of their centrality in the network).

Two things are of particular note here. First is that these individuals principally work for either one of the main professional associations of accountants (10/29) or for the initiatives themselves (9/29). The primary links, and thus we infer the principal routes for flows of information, ideas, and entrepreneurial authority across the initiatives, come thus from these sorts of organizations. Only three work for one of the big accounting firms directly, one works for a major bank, one works for an investment company, and one works for a transnational corporate organization (the World Economic Forum). This is consistent with a set of claims about the epistemic professional authority of accounting organizations on the one hand, but also that the initiatives themselves play a significant role in shaping the generation of new initiatives. In this sense, we could suggest the emergence of a specific sort of sustainability accounting professional identity.

The disclosure frameworks developed by each SAI provide some evidence that supports the emergence of a new professional identity as they reveal how accounting and ESG logics are combined in ways that are clearly separate from those adopted by accounting firms. This separation also demonstrates how SAI frameworks do not align fully with arguments of neoliberal co-optation as accounting firms contest expanding disclosure to ESG information. Deloitte, for example, argued that the CDSB's framework needed to improve its capacity to demonstrate that disclosure of climate change risks is cost-effective (CDSB, 2010b: 4). Ernst $\&$ Young argued that IIRC disclosure would likely be redundant with existing reporting requirements disputing how ESG information would be any different from existing financial reports since report preparers are already required to identify ESG impacts that are material (Ernst \& Young 2013). These positions confirm findings that despite participation in SAI, accounting firms remain hesitant about using their expertise to improve ESG reporting in financial statements (O'Dwyer et al., 2011). At the same time, however, opposition from 


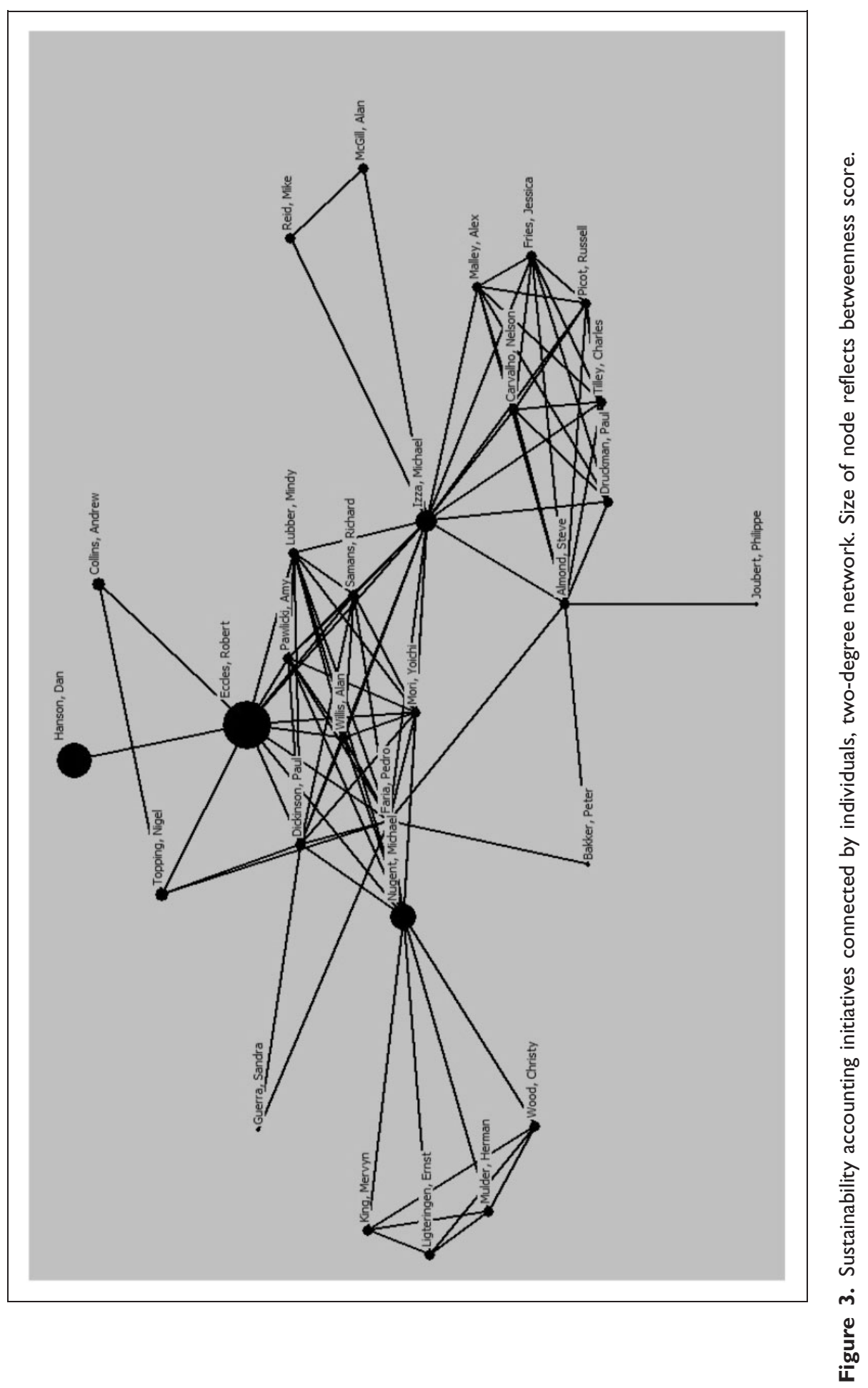


Table 2. Organization, profession, and nationality of individuals connecting sustainability accounting initiatives, organized according to betweenness score.

\begin{tabular}{|c|c|c|c|c|c|}
\hline Name & $\begin{array}{l}\text { Betweenness } \\
\text { score }\end{array}$ & $\begin{array}{l}\text { Sustainability } \\
\text { accounting } \\
\text { initiative }\end{array}$ & Name of home organization & $\begin{array}{l}\text { Type of home } \\
\text { organization }\end{array}$ & Profession \\
\hline Eccles, Robert & $|76| .47 \mid$ & $\begin{array}{l}\text { IIRC, CDSB, } \\
\text { SASB }\end{array}$ & Harvard University & University & Academic \\
\hline Hanson, Dan & 1266.016 & IIRC, SASB & Blackrock & Corporate & Corporate \\
\hline Nugent, Michael & 914.429 & IIRC, CDSB & $\begin{array}{l}\text { International Federation of } \\
\text { Accountants (IFAC) }\end{array}$ & Accounting & Accountant \\
\hline Izza, Michael & 734.355 & $\begin{array}{l}\text { IIRC, CDSB, } \\
\quad \text { A4S }\end{array}$ & $\begin{array}{l}\text { Institute of Chartered } \\
\text { Accountants in England } \\
\text { and Wales (ICAEW) }\end{array}$ & Accounting & Accountant \\
\hline Topping, Nigel & 331.263 & CDSB, SASB & CDP & NGO & Corporate \\
\hline Collins, Andrew & 321.614 & CDSB, SASB & SASB & NGO & Accountant \\
\hline Faria, Pedro & 295.345 & IIRC, CDSB & CDP & NGO & $\begin{array}{l}\text { Business- } \\
\quad \text { environment }\end{array}$ \\
\hline Lubber, Mindy & 276.071 & IIRC, CDSB & Ceres & NGO & Corporate \\
\hline Mori, Yoichi & 276.071 & IIRC, CDSB & $\begin{array}{l}\text { Japanese Institute of Certified } \\
\text { Public Accountants }\end{array}$ & Accounting & Accountant \\
\hline Pawlicki, Amy & 276.071 & IIRC, CDSB & $\begin{array}{l}\text { American Institute of } \\
\text { Certified Public } \\
\text { Accountants (AICPA) }\end{array}$ & Accounting & Accountant \\
\hline Samans, Richard & $276.07 \mid$ & IIRC, CDSB & World Economic Forum & Corporate & Corporate \\
\hline Willis, Alan & 276.071 & IIRC, CDSB & $\begin{array}{l}\text { Canadian Institute of } \\
\text { Chartered Accountants } \\
\text { (CICA) }\end{array}$ & Accounting & Accountant \\
\hline Dickenson, Paul & 276.071 & $\begin{array}{l}\text { IIRC, CDP, } \\
\text { CDSB }\end{array}$ & CDP & NGO & Corporate \\
\hline King, Mervyn & 261.442 & IIRC, GRI & University of South Africa & University & Lawyer \\
\hline Wood, Christy & 261.442 & IIRC, GRI & $\begin{array}{l}\text { Global Reporting Initiative } \\
\text { (GRI) }\end{array}$ & NGO & Corporate \\
\hline Ligteringen, Ernst & 261.442 & IIRC, GRI & $\begin{array}{l}\text { Global Reporting Initiative } \\
\text { (GRI) }\end{array}$ & NGO & Corporate \\
\hline Mulder, Herman & 261.442 & IIRC, GRI & $\begin{array}{l}\text { Global Reporting Initiative } \\
\text { (GRI) }\end{array}$ & NGO & Corporate \\
\hline Reid, Mike & 260.277 & CDSB, A4S & Grant Thornton & Accounting & Accountant \\
\hline McGill, Alan & 260.277 & CDSB, A4S & PWC & Accounting & Accountant \\
\hline Druckman, Paul & 257.318 & IIRC, A4S & IIRC & NGO & Accountant \\
\hline Carvalho, Nelson & 257.318 & IIRC, A4S & University of Sao Paulo & University & Academic \\
\hline Almond, Steve & 257.318 & IIRC, A4S & Deloitte & Accounting & Accountant \\
\hline Picot, Russell & 257.318 & IIRC, A4S & HSBC & Corporate & Accountant \\
\hline Malley, Alex & 257.318 & IIRC, A4S & $\begin{array}{l}\text { Chartered Professional } \\
\text { Accountants Australia }\end{array}$ & Accounting & Accountant \\
\hline Fries, Jessica & 257.318 & IIRC, A4S & A4S & NGO & Accountant \\
\hline Tilley, Charles & 257.318 & IIRC, A4S & $\begin{array}{l}\text { Chartered Institute of } \\
\text { Management Accountants } \\
\text { (CIMA) }\end{array}$ & Accounting & Accountant \\
\hline Adams, Roger & 233.653 & A4S, GRI & $\begin{array}{l}\text { Association of Chartered } \\
\text { Certified Accountants } \\
\text { (ACCA) }\end{array}$ & Accounting & Accountant \\
\hline Bakker, Peter & 10.624 & IIRC & $\begin{array}{l}\text { World Business Council for } \\
\text { Sustainable Development } \\
\text { (WBCSD) }\end{array}$ & Corporate & Corporate \\
\hline
\end{tabular}


Table 2. Continued.

\begin{tabular}{|c|c|c|c|c|c|}
\hline Name & $\begin{array}{l}\text { Betweenness } \\
\text { score }\end{array}$ & $\begin{array}{l}\text { Sustainability } \\
\text { accounting } \\
\text { initiative }\end{array}$ & Name of home organization & $\begin{array}{l}\text { Type of home } \\
\text { organization }\end{array}$ & Profession \\
\hline Guerra, Sandra & 7.583 & IIRC, CDP & $\begin{array}{l}\text { Brazilian Institute for } \\
\quad \text { Corporate Governance }\end{array}$ & Corporate & Corporate \\
\hline Joubert, Phillipe & 3.679 & $A 4 S, W B C S D$ & $\begin{array}{l}\text { World Business Council for } \\
\text { Sustainable Development } \\
\text { (WBCSD) }\end{array}$ & Corporate & Corporate \\
\hline
\end{tabular}

Note: IIRC: International Integrated Reporting Committee; CDSB: Climate Disclosure Standards Board; SASB: Sustainability Accounting Standards Board; A4S: Accounting for Sustainability; CDP: Carbon Disclosure Project. Note that this is the betweenness score calculated for the network as a whole, whereas the size of the node in the figure is recalculated by the software when it moves to a two-degree network, so will not be identical.

within the accounting industry toward some of SAI frameworks confirms an emerging "separation" from existing accounting logics, and space for new professional logics to take hold.

\section{Experimental governance}

While professions may play a significant role in the emergence and dynamics of SAI, we can also interpret the shifts in approach over time, the interconnections between the membership of different initiatives, as in part evidence that the logics of developing rules for $44 \mathrm{~S}$, or even something ostensibly narrower such as carbon, exceed the existing professional expertise of accountants. They are thus engaged in an iterative process of attempting to adapt their existing knowledge to the new context of having to incorporate, in varying contexts (from individual projects through to overall corporate financial accounts) indices of sustainability into corporate accounting systems. This reflects a third, emerging strand of research into private or transnational environmental governance, which emphasizes the experimental character of such governance.

Since actors do not really know how to govern effectively in this area, governance initiatives are inevitably drawn into a mode of "learning by doing," a metaphor deployed routinely in climate change governance (Paterson, 2014: 163-167). Climate change governance initiated by various types of actors, has been thus conceptualized as a space of experimentation (Bulkeley and Castán Broto, 2013; Bulkeley et al., 2015; Hoffmann, 2011). In this view, those seeking to govern in order to produce sustainability transitions operate with radically imperfect information and thus seek to govern in an experimental fashion, trying out one set of practices or rules and adapting them as they learn about their effects. From this perspective, SAI can be understood as an iterative process of generating knowledge regarding how to measure and account for environmental degradation within corporate accounting, where the production of this knowledge exceeds the limits of what preexisting professional knowledge claims - notably those of accountants - can deliver. Governance networks are thus the site of collective knowledge production and learning, as well as representing competing sets of claims about how this governance should be effected. ${ }^{6}$

Another way of understanding this process is that the character of sustainability shapes what it means to be an accountant. At the same time, as accountants attempt to depoliticize sustainability through the assertion of epistemic authority, subjecting it to the application of 
technical rules that they are the authorized actors to control, the character of sustainability re-politicizes this authority as it forces them to address the limits of their epistemic authority and thus what it means to be an accountant in this context.

Research on the changing role of professionals helps provide a new angle on this experimental governance, by focusing on the professionals seeking strategies for governing in an arena of significant uncertainty, rather than on the organizations involved. The process of learning-by-doing involved in experimental governance is not bound by a preexisting organizational mandate as professionals use their autonomy to search for consensus on expertise that is a precursor to reorganization as new information emerges. Figures 4 and 5 show the development of these initiatives over time. These images are organized chronologically, with the earliest on the left of the images. ${ }^{7}$

A number of things can be inferred from these figures. First, the earlier networks emerged in a number of disparate institutional contexts. One is a transnational business network (WBCSD) collaborating with a major research NGO (WRI), another is an international organization (UNEP) acting entrepreneurially to bring together institutional investors to develop means of assessing corporate GHG performance, and the third is an ENGO initiative. Notable in this early stage is that in the individual network, UNEP-FI is not connected to any later initiatives. ${ }^{8}$ But in the employer network, UNEP and UNEP-FI ${ }^{9}$ play important roles in connecting the early initiatives. We interpret this as an act of institutional entrepreneurship, UNEP-FI in particular learning from the limits of its own initiatives to forge links with others and build later initiatives, notably CDP.10 A similar phenomenon can be seen in GRI employees making up significant links from GRI itself to other initiatives.

Second, later initiatives become broader and more all encompassing. This reflects learning on the basis of earlier initiatives. But it remains the case that no one organization is able to claim dominance within the field, in part because the problem of how to successfully account for ESG reporting is not yet "solved." Thus, we see a continued experimentation around different techniques for accounting, different interests across the field, and different strategies in relation to the sorts of coalitions to be built and the relationship between private and state governance envisaged.

Evidence of this experimentation and "learning by doing" can also be found in SAI disclosure frameworks. First, in addition to external fragmentation between initiatives over how to account for ESG information, there is also a great deal of internal uncertainty. The measurement of ESG information is incredibly complex, which contrasts accounting logics that are designed to streamline measurement and communication of financial information. For example, the American Institute of Certified Professional Accountants points out how the CDSB's efforts to report climate change risks suffers from an a "lack of consensus about climate change impacts" that "will make it very challenging for companies to find the appropriate measure for meaningful disclosure" (American Institute of Certified Public Accountants, 2009). KPMG suggested that the firm "may not have the relevant expertise" to audit the CDSB's reporting framework, and that the IIRC's framework's requirement to report information on natural and social "capitals" would struggle to be understood by report preparers (KPMG, 2009). To accommodate this uncertainty, SAI framework's have rejected the U.S. "rules-based" approach to financial accounting in favor of a "principles-based" approach which is supported by many European standard setters (CDSB, 2012; IIRC, 2013d; SASB, 2013d). The principles-based approach gives accountants more flexibility to interpret and make their own judgments necessary to reduce uncertainty. This decision further contrasts arguments that SAI frameworks will reduce measurements of ESG 

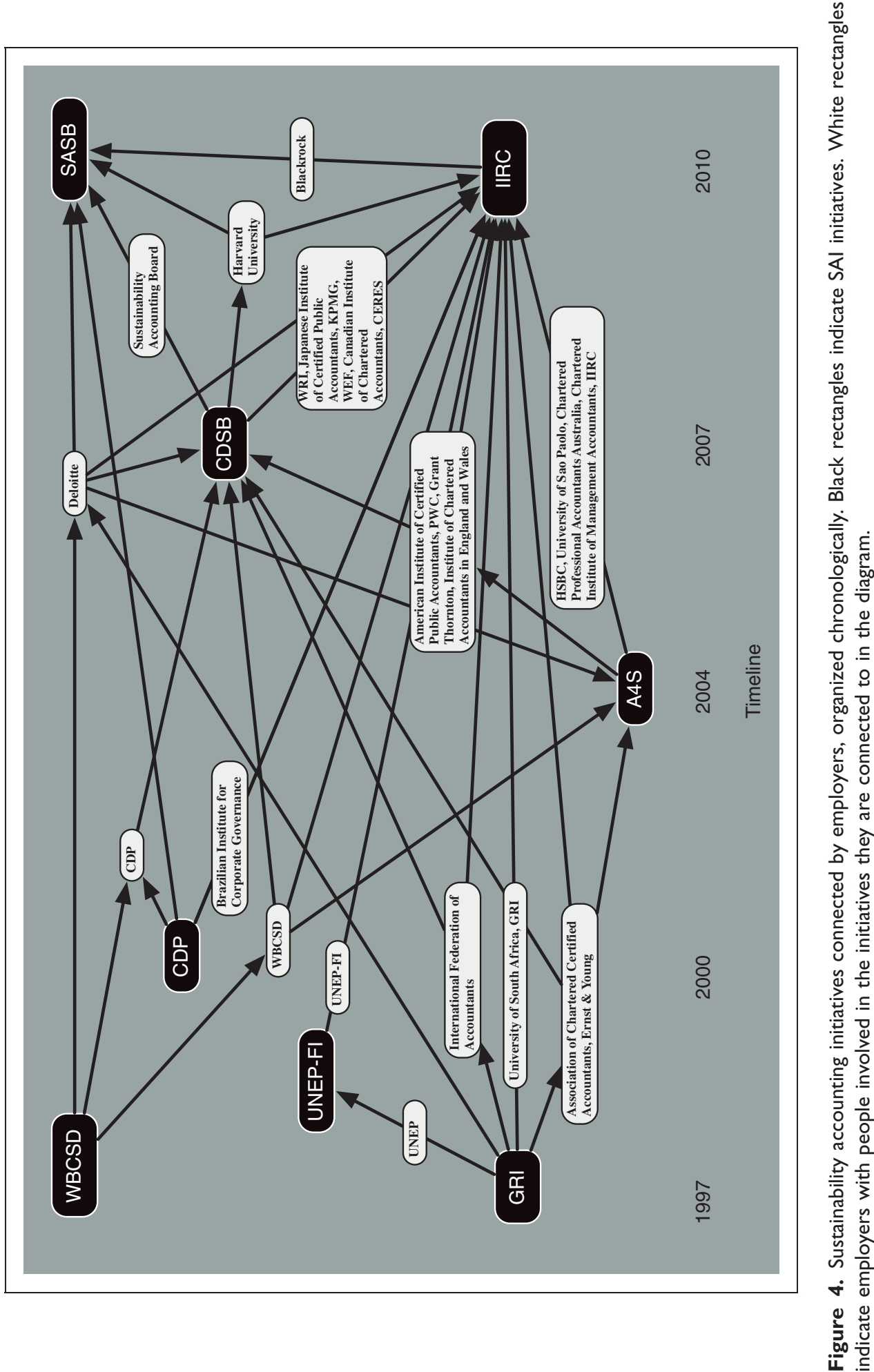

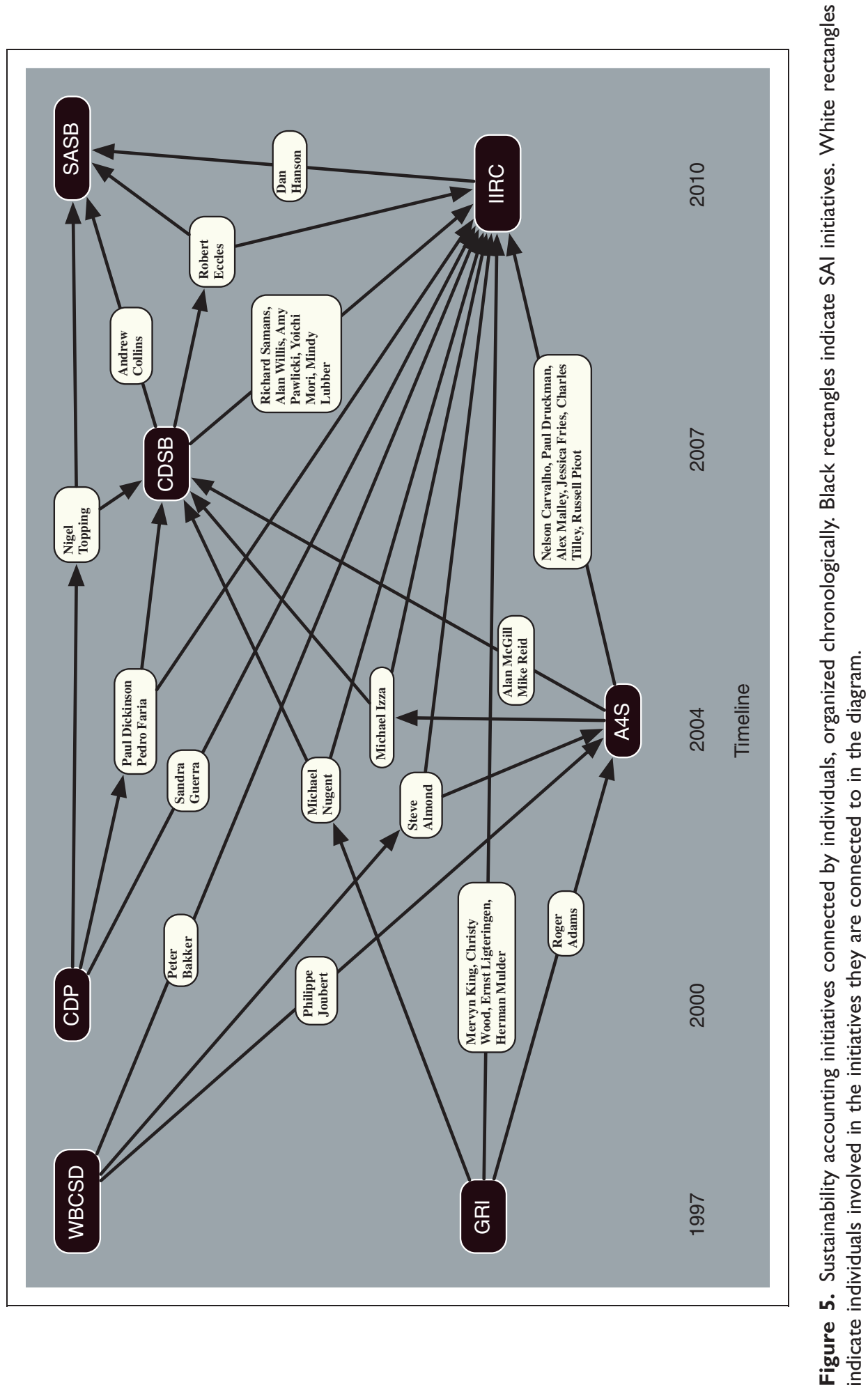
information into "boiler-plate" metrics, which is promoted by the rules-based approach (Rogers, 2005).

Second, despite significant uncertainty, SAI's try and blend ESG and financial accounting concepts and then seek feedback through consultations. The SASB's reporting standards, for example, include a "forward looking adjustment" that asks reporting organizations to disclose ESG information identified by scientific research as a potential impact on financial performance, even if it falls outside the traditional definition of materiality or investor interest (SASB, 2013d: 16). The IIRC has made a similar adjustment to its definition of financial reporting model by encouraging disclosure that captures "relevant" information beyond a strict interpretation of investor interests, including "factors beyond financial capital alone" (IIRC, 2013c: 6). While accountants, report preparers, and investors may struggle to understand these methodologies, each SAI has committed to a process of continuous improvement whereby different versions of their frameworks will be produced based on feedback from end users (CDSB, 2012; IIRC, 2013b; SASB, 2013c).

\section{Conclusions}

This paper has explored the character of transnational private governance, focusing on the development of corporate ESG reporting through what we call SAI. To understand how these initiatives contribute to debates on private governance, a combination of historical analysis on the emergence of SAI, SNA of the participants involved in each initiative, and assessment of emerging disclosure frameworks was employed. This approach facilitated analysis of the field of ESG reporting as it evolved allowing a more in-depth assessment of competing accounts of private governance, by exploring the specificities of the links between the different governance initiatives involved.

This assessment of SAI, and particularly the use of SNA, helps contribute to a better understanding of the dynamics of private environmental governance. While there is some evidence that SAI does reflect a site of neoliberal contestation, or the dominant narrative within literature on private governance, processes of professionalization and experimentation suggest a much more complex and nuanced phenomenon. Neoliberal contestation infers that SAI is a forum where "capital" and "civil society" realms converge and contest, but professionalization and experimentation lend more focus to the individual connections and the practices they are developing that blurs the distinction between these two realms. This claim is prominent in emerging research that problematizes the public-private divide in transnational governance. Our SNA demonstrated that it is indeed highly difficult to identify actors or initiatives as clearly "public" or "private" in character, or to connect such identities to the elaboration of specific arguments about how SAI as a form of governance should be pursued. While such initiatives do entail "market-led" environmental governance, as would be expected by the focus on neoliberalism, they nevertheless involve legitimation activities that depend on much more open-ended consultation and deliberation that are difficult to understand as simple appropriations by neoliberal forces (see also Bernstein, 2014). Similarly, such experimentation inherently leads to fragmentation, multiple-decision making sites, and ultimately, uncertainty, as we have shown in our historical development of the initiatives. This uncertainty "re-politicizes" what are traditionally technical debates as actors take on different interests that limit any simplified conception of outcomes as evidence of a public or private trade-off.

Evidence supporting this link between notions of professionalization and experimentation, and research on the public-private divide can be found in the way 
accounting firms often support the claims of civil society actors even it if opposes the industry's own expertise. Accounting organizations often questioned the use of financial reporting models as potentially ineffective for new ESG frameworks, which parallels arguments made by civil society and NGO interests. This appears to reflect the "epistemic arbitrage" of key brokers in the network who straddle accounting and NGO worlds.

The analysis is highly suggestive both that SNA can be a useful method for exploring Avant et al.'s (2010) "who governs the globe?" question, extending existing analyses of the ways that processes of professionalization and experimentation call into question hard and fast boundaries between public and private. It also enables us to identify how a field of governance evolves over time, and thus the processes of learning and adaptation that go on with the field, as specific actors act on a particular identified problem such as how to incorporate sustainability questions into financial accounting regimes. In our case, this could be extended via further analyses of the technical committees involved, archival work to uncover more detail of agents involved in these initiatives, and further combination with discourse analysis to explore the debates about how to govern sustainability via accounting systems. But the method we outline here could also be adapted to explore other fields of environmental governance in fruitful ways.

\section{Conflict of interest}

The author(s) declared no potential conflicts of interest with respect to the research, authorship, and/or publication of this article.

\section{Funding}

The author(s) received no financial support for the research, authorship, and/or publication of this article.

\section{Notes}

1. The financial industry is defined as sectors that provide financial services including banking, investing, accounting, credit rating, and insurance.

2. We define the accounting industry as defined as the interests generated by the Big Four accounting firms and their professional organizations.

3. The exceptions are UNEP FI where archive data were available, and also we have included data concerning members of technical committees involved in the initiatives where available.

4. UNEP-FI originated as the UNEP Insurance Initiative, but in 2003 adopted its current name.

5. Of course, this figure may reflect either the specific domination of the SAI phenomenon by US and UK actors or the more general domination of the accounting world by those two countries. This data does not enable us to distinguish between these two possibilities. But either way, it demonstrates the enormous domination of this field by actors from the neoliberal heartland. Perhaps interestingly, there are more from the UK than the US involved. This may reflect simply the stronger development of climate governance in the UK in general, and thus a more developed network of professionals involved in the field as well as stronger corporate expectations of the need to adapt to carbon governance over time.

6. This should be distinguished from the account of experimental governance that involves the intentional design of strategies within an organization that explicitly invoke the notion of scientific experiments (see Overdevest and Zeitlin, 2012).

7. Note, this chronological organization is not generated automatically within the SNA software. Rather, we have placed the initiatives manually in chronological order of their emergence. These images have been redrawn manually on the basis of Netdraw images, using Omnigraffle. 
8. We know in fact that Tessa Tennant, who was in the UNEP-FI initiative, was also involved in establishing CDP. As ever in this sort of analytic exercise, the means of data collection always leave some lacunae. See description of methods above.

9. It is worth distinguishing between these two since UNEP-FI had significant autonomy to act entrepreneurially within UNEP as an organization. The UNEP connection is Sylvie Lemmett, who was involved in GRI, but not the UNEP-FI initiative.

10. The role of UNEP-FI in the creation of CDP was also confirmed in interview with the Director of UNEP-FI. Interview, Paul Clements-Hunt, UNEP, Geneva, 25 January 2007. See Paterson (2010: 358), for more details.

\section{References}

A4S (2014) A4S Principles for the ABN. The Prince's Accounting for Sustainability Project. Available at: http://www.accountingforsustainability.org/international_network/forum-principles

Abbott A (2005) Linked ecologies: States and universities as environments for professions. Sociological Theory 23(3): 245-275.

AccountAbility (2013) Comments to Draft International IR Framework. July 15. Available at: http:// www.theiirc.org/wp-content/uploads/2013/08/197_AccountAbility.pdf

11 Adams J (2007) Highlighting the problem. Accountancy Age, January 11

American Institute of Certified Public Accountants (2009) Re: The Climate Disclosure Standards Board (CDSB) Reporting Framework. November 11. Available at: http://www.aicpa.org/ interestareas/businessindustryandgovernment/downloadabledocuments/aicpa $\% 20$ comment $\% 20$ letter\%20on\%20climate.pdf

Andonova LB, Betsill MM and Bulkeley H (2009) Transnational climate governance. Global Environmental Politics 9(2): 52-73.

Andrew J and Cortese C (2013) Free market environmentalism and the neoliberal project: The case of the Climate Disclosure Standards Board. Critical Perspectives on Accounting 24: 397-409.

Barnett M and King A (2008) Good fences make good neighbours: A longitudinal analysis of an industry self-regulatory institution. Academy of Management Journal 51(6): 1150-1170.

Bernstein S (2014) The publicness of non-state global and environmental governance. In: Best $\mathbf{J}$ and Gheciu A (eds) The Return of the Public in Global Governance. Cambridge, UK: Cambridge University Press, pp. 120-149.

Best $\mathbf{J}$ and Gheciu A (2014) Theorizing the public as practices: Transformations of the public in historical context. In: Best J and Gheciu A (eds) The Return of the Public in Global Governance. Cambridge, UK: Cambridge University Press, pp. 1-15.

Borgatti S, Everett M and Freeman L (2002) Ucinet for Windows: Software for Social Network Analysis. Harvard MA: Analytic Technologies.

Botzem S (2008) Transnational expert-driven standardisation: Accountancy governance from a professional point of view. In: Graz J-C and Nolke A (eds) Transnational Private Governance and Its Limits. II: Routledge, pp. 44-57.

Brown HS, de Jong M and Lessidrenska T (2009) The rise of the global reporting initiative: A case of institutional entrepreneurship. Environmental Politics 18(2): 182-200. DOI: 10.1080/0964401080 2682551.

Bulkeley H, Andonova LB, Backstrand K, et al. (2012) Governing climate change transnationally: Assessing the evidence from a database of sixty initiatives. Environment and Planning C: Government and Policy 30: 591-612.

Burt R (2010) Neighbor Networks. Oxford, UK: Oxford University Press.

Buthe T and Mattli W (2012) The New Global Rulers: The Privatization of Regulation in the World Economy. Princeton, NJ: Princeton University Press.

Carbon Tracker (2012) Unburnable Carbon-Are the World's Financial Markets Carrying a Carbon Bubble? London: Carbon Tracker Initiative. Available at: http://www.carbontracker.org/wpcontent/uploads/downloads/2012/08/Unburnable-Carbon-Full1.pdf 
Carbon Tracker (2014) Carbon Supply Cost Curves: Evaluating Financial Risk to Oil Capital Expenditures. London: Carbon Tracker Initiative. Available at: file://Users/jasonthistlethwaite/ Documents/Thesis\%20Work/Jobs\%20and\%20Postdocs/CCAP\%20Report/Consulting/CIGI/ Carbon \%20Tracker\%20-\%20Stranded\%20Assets.pdf

Cashore B, Auld G and Newsom D (2004) Governing Through Markets: Forest Certification and the Emergence of Non-State Authority. New Haven, CT: Yale University Press.

CDP (2013) Our climate change work. CDP. Available at: https://www.cdproject.net/en-US/ Programmes/Pages/climate-change-programs.aspx

1615 CDSB (2010a) Report on Consultation About CDSB's Reporting Framework. CDSB.

CDSB (2010b) Climate Change Reporting Framework-Edition 1.0. CDSB.

CDSB (2012) Climate Change Reporting Framework-Edition 1.1. London, UK: Climate Disclosure Standards Board. Available at: http://www.cdsb.net/sites/cdsbnet/files/cdsbframework_v1-1.pdf

CDSB (2013) CDSB: History and Mission. CDSB. Available at: http://www.cdsb.net/about-cdsb/ history-and-mission

CDSB (2014) Technical Working Group. Climate Disclosure Standards Board. Available at: http:// cdsb.net/about-cdsb/leadership-governance/technical-working-group

Clapp J (1998) Privatization of global environmental governance: ISO 14000 and the developing world. Global Governance 4: 295-316.

Clapp J and Helleiner E (2012) International political economy and the environment: Back to the basics? International Affairs 88(3): 485-501.

Clapp J and Utting P (2009) Corporate Accountability and Sustainable Development. W: Oxford University Press.

Cutler AC, Haufler V and Porter T (1999) Private Authority and International Affairs. W: SUNY Press.

Ernst \& Young (2013) Consultation Draft of the International $<\mathrm{IR}>$ Framework. 15 July. Available at: http://www.theiirc.org/wp-content/uploads/2013/08/252_Ernst-Young-Global-Limited.pdf

European Coalition for Corporate Justice (2013) Comments on Draft International IR Framework. 15 July. Available at: http://www.theiirc.org/wp-content/uploads/2013/08/218_European-Coalitionfor-Corporate-Justice.pdf

Falkner R (2003) Private environmental governance and international relations: Exploring the links. Global Environmental Politics 3(2): 72-87.

Gore Al and Blood D (2013) The coming carbon asset bubble. The Wall Street Journal, 29 October. Available at: http://online.wsj.com/news/articles/SB1000142405270230465510457916366346433 9836

Gray R (2001) “Thirty years of social accounting, reporting and auditing: What (if anything) have we learnt?" Business Ethics, A European Review 10: 9-15.

Green J (2010) Private standards in the climate regime: The greenhouse gas protocol. Business \& Politics 12(3): 1-37.

Green J (2013) Order out of chaos: Public and private rules for managing carbon. Global Environmental Politics 13(2): 1-25.

Green J (2014) Rethinking Private Authority: Agents and Entrepreneurs in Global Environmental Governance. Princeton: Princeton University Press.

Gupta A (2008) Transparency under scrutiny: Information disclosure in global environmental governance. Global Environmental Politics 8(2): 1-7.

Hadden J (2014) Explaining variation in transnational climate change activism: The role of inter-movement spillover. Global Environmental Politics 14(2): 7-25. DOI: 10.1162/ GLEP_a_00225.

Hoffmann MJ (2011) Climate Governance at the Crossroads: Experimenting with a Global Response after Kyoto. Oxford: University of Oxford.

Humphreys D (2006) Logjam: Deforestation and the Crisis of Global Governance. Cambridge: Cambridge University Press.

IASB (2008) An Improved Conceptual Framework for Financial Reporting. Available at: http:// www.iasb.org/NR/rdonlyres/464C50D6-00FD-4BE7-A6FF-1BEAD353CD97/0/conceptual_ framework_exposure_draft.pdf 
IIRC (2013a) Framework development. International Integrated Reporting Committee. Available at: http://www.theiirc.org/resources-2/framework-development/

IIRC (2013b) Working Group. International Integrated Reporting Committee. Available at: http:// www.theiirc.org/the-iirc/structure-of-the-iirc/iirc-working-group/

IIRC (2013c) Consultation Draft of the International $<I R>$ Framework. London, UK: International Integrated Reporting Committee. Available at: http://www.theiirc.org/wp-content/uploads/ Consultation-Draft/Consultation-Draft-of-the-InternationalIRFramework.pdf

IIRC (2013d) Basis for Conclusions. London, UK: International Integrated Reporting Committee. Available at: http://www.theiirc.org/wp-content/uploads/2013/12/13-12-08-Basis-for-conclusionsIR.pdf

IIRC (2013e) The International $<I R>$ Framework. London, UK: International Integrated Reporting Committee. Available at: http://www.theiirc.org/wp-content/uploads/2013/12/13-12-08-THEINTERNATIONAL-IR-FRAMEWORK-2-1.pdf

King A, Prado AM and Rivera J (2012) Industry self-regulation and environmental protection. In: Bansal P and Hoffman AJ (eds) The Oxford Handbook of Business and the Natural Environment. Oxford University Press, pp. 101-121. Available at: http://www.oxfordhandbooks.com/view/ 10.1093/oxfordhb/9780199584451.001.0001/oxfordhb-9780199584451-e-6

Kolk A, Levy D and Pinkse J (2008) Corporate responses in an emerging climate regime: The institutionalization and commensuration of carbon disclosure. European Accounting Review 17(4): 719-745.

KPMG (2009) Exposure Draft The Climate Disclosure Standards Board Reporting Framework. September 25. Available at: http://www.cdsb.net/climate-change-reporting-framework/updatesframework

Leggett J (2012) Carbon bubble is the real risk for markets. The Financial Times, August 30. Available at: http://www.ft.com/cms/s/0/629f9a52-2283-11e2-b606-00144feabdc0.html\#axzz38OEWOAhh

Living Economies Forum (2013) Feedback to the International Integrated Reporting Council (IIRC) on the Integrated Reporting Prototype Framework Working Document. July. Available at: http:// www.theiirc.org/wp-content/uploads/2013/08/096_Living-Economies-Forum.pdf

Lovell H and MacKenzie D (2011) Accounting for carbon: The role of accounting professional organisations in governing climate change. Antipode 43(3): 704-731.

Macleod M and Park J (2011) Financial activism and global climate change: The rise of investor-driven governance networks. Global Environmental Politics 11(2): 54-74.

Malsch B (2013) Politicizing the expertise of the accounting industry in the realm of corporate social responsibility. Accounting, Organizations and Society 38: 149-168.

Martinez-Diaz L (2005) Strategic experts and improvising regulators: Explaining the IASC's rise to global influence, 1973-2001. Business and Politics 7(3). Available at: http://www.bepress.com/bap/ vol7/iss $3 /$ art3

Miller P (1994) Accounting as a social and institutional practice. In: Miller P and Hopwood A (eds) Accounting as a Social and Institutional Practice. Cambridge, UK: Cambridge University Press, pp. II-II.

Miller P and O'Leary T (1987) Accounting and the construction of the governable person. Accounting, Organizations and Society 12(3): 235-265.

Newell P (2001) Environmental NGOs, TNCs, and the question of governance. In: Stevis D and Assetto V (eds) The International Political Economy of the Environment: Critical Perspectives. IPE Yearbook 12. Boulder: Lynne Rienner Publishers, pp. 85-107.

Newell P and Paterson M (2010) Climate Capitalism: Global Warming and the Transformation of the Global Economy. Cambridge: Cambridge University Press.

Nolke A and Perry J (2007) The power of transnational private governance: Financialization and the IASB. Business \& Politics 9(3): 1-34.

O'Dwyer B, Owen D and Unerman J (2011) Seeking legitimacy for new assurance forms: The case of assurance on sustainability reporting. Accounting, Organizations and Society 36: 31-52.

Overdevest C and Zeitlin J (2012) Assembling an experimentalist regime: Transnational governance interactions in the forest sector. Regulation \& Governance ㅍ: II-II. 
Paterson M (2014) Climate re-public: Practice public space. In: Best J and Gheciu A (eds) The Return of the Public in Global Governance. Cambridge, UK: Cambridge University Press, pp. 149-173.

Paterson M, Hoffmann M, Betsill M, et al. (2014) The micro foundations of policy diffusion toward complex global governance: An analysis of the transnational carbon emission trading network. Comparative Political Studies 47(3): 420-449. DOI: 10.1177/0010414013509575.

Pattberg P (2007) Private Institutions and Global Governance: The New Politics of Environmental Stability. Cheltenham, UK: Edward Elgar.

Pattberg P and Stripple J (2008) Beyond the public and private divide: Remapping transnational climate governance in the 21st century. International Environmental Agreements 8: 367-388.

Perry $\mathbf{J}$ and Nolke A (2006) The political economy of international accounting standards. Review of International Political Economy 13(4): 559-586.

Porter T (2005) Private authority, technical authority, and the globalization of accounting standards. Business and Politics 7(3): 1-32.

Power M (1997) Expertise and the construction of relevance: Accountants and environmental audit. Accounting, Organizations and Society 22: 123-146.

Rogers G (2005) Financial Reporting of Environmental Liabilities and Risks after Sarbanes-Oxley. Wiley \& Sons.

Sadler D and Lloyd S (2009) Neo-liberalising corporate social responsibility: A political economy of corporate citizenship. I0: 613-622.

SASB (2013a) Determining materiality. Sustainability Accounting Standards Board. Available at: http://www.sasb.org/materiality/determining-materiality/

SASB (2013b) Standards council. Sustainability Accounting Standards Board. Available at: http:// www.sasb.org/sasb/standards-council/

SASB (2013c) Vision and mission. Sustainability Accounting Standards Board. Available at: http:// www.sasb.org/sasb/vision-mission/

SASB (2013d) Conceptual framework. Sustainability Accounting Standards Board. Available at: http:// www.sasb.org/wp-content/uploads/2013/10/SASB-Conceptual-Framework-Final-Formatted-1022-13.pdf

Scott J (2012) Social Network Analysis, 3rd ed. Los Angeles: Sage Publications.

Seabrooke L (2014a) Epistemic arbitrage: Transnational professional knowledge in action. Journal of Professions and Organizations 1(1): प- 1 .

Seabrooke L (2014b) Identity switching and transnational professionals. International Political Sociology || || ||-

Sinclair TJ (1994) Passing judgement: Credit rating processes as regulatory mechanisms of governance in the emerging world order. Review of International Political Economy 1(1): 133-159. DOI: $10.1080 / 09692299408434271$.

Stephan B (2012) Bringing discourse to the market: The commodification of avoided deforestation. Environmental Politics 21(4): 621-639. DOI: 10.1080/09644016.2012.688357.

The Economist (2014) The elephant in the atmosphere. The Economist, 19 July. Available at: http:// www.economist.com/news/business/21607838-managers-biggest-oil-firms-clash-investors-overclimate-change-elephant

Thistlethwaite $\mathbf{J}$ (2011) Counting the environment: The environmental implications of international accounting standards. Global Environmental Politics 11(2): 75-97.

Tsingou E (2010) Transnational governance networks in the regulation of finance-The making of global regulation and supervision standards in the banking industry. In: Ougaard M and Leander A (eds) Theoretical Perspectives on Business and Global Governance: Bridging Theoretical Divides. London: Routledge, pp. I-T. 